\title{
AKIBAT HUKUM PERJANJIAN KREDIT YANG OBYEK JAMINANNYA BUKAN ATAS NAMA DEBITUR
}

\author{
Bagus Priyo Mahendra, Aminah \\ Program Studi Magister Kenotariatan, \\ Fakultas Hukum, Universitas Diponegoro
}

\begin{abstract}
In order to ensure that the debtor performs its obligations, usually in the credit agreement is bound by a guarantee of mortgages or fiducia guarantees to avoid non-fulfillment of the debtor's liability when wanprestasi. The principle of prudence and the maximum crediting limit are important. In practice, the violation occurs as happened to PT BPR " $X$ " in Semarang where the security object is not on behalf of the debtor and there is no power of attorney from the Land Certificate holder to the debtor. Normative legal research methods. The results show that PT $B P R$ " $X "$ " has violated prudential principles and $5 C$ principles. This is evidenced by the existence of clauses in the agreement that enlarge the guarantee of the Certificate of Property to the land which is not on behalf of the debtor. The legal consequence is that the guarantee can not be sold or auctioned. The position of the creditor is very weak and ineffective when settled through the court.
\end{abstract}

Keywords : Legal Effect, Guarantee Not On Behalf of Debtor, Credit Agreement

\begin{abstract}
Abstrak
Untuk menjamin debitur menjalankan kewajibannya, biasanya dalam perjanjian kredit diikat sebuah jaminan hak tanggungan atau jaminan fiducia untuk menghindari tidak terpenuhinya kewajiban debitur bilamana wanprestasi.Prinsip kehatia-hatian dan batas maksimum pemberian kredit penting. Dalam praktik, pelanggaran terjadi sebagaimana yang terjadi pada PT BPR " $X$ " di Semarang di mana obyek jaminan tidak atas nama debitur dan tidak ada surat kuasa dari pemilik Sertifikat Tanah kepada debitur. Metode penelitian hukum normatif. Hasil penelitian menunjukkan PT BPR " $X$ ” telah melanggar prinsip kehati-hatian dan prinsip 5C. Hal itu terbukti dengan adanya klausula dalam perjanjian yang mencatumkan jaminan Sertifikat Hak Milik atas tanah yang bukan atas nama debitur. Akibat hukumnya adalah jaminan tersebut tidak bisa dijual atau dilelang.Posisi kreditur sangat lemah .dan tidak efektif bilamana diselesaikan melalui pengadilan.
\end{abstract}

Kata Kunci : Akibat Hukum, Jaminan Bukan Atas Nama Debitur, Perjanjian Kredit 


\section{A. Pendahuluan}

Secara umum bank berfungsi untuk menghimpun dana dari masyrakat luas(funding) dan menyalurkan dalam bentuk pinjaman atau kredit(lending) untuk berbagai tujuan masyarakat. Penyaluran dana tersebut didasarkan atas kebutuhan masyaarakat baik perorangan, badan hukum maupun non badan hukum dengan alasan berbagai kepentingan dan untuk menjalanka aneka usaha sebagai awal atau pengembangan bisnis baik yang bersifat produktif maupun yang konsumtif. Dalam penyaluran kredit atau pinjaman kepada debitur, bank sebagai debitur yang memiliki dana patut mendapat perlindungan yang layak agar dana pinjaman tersebut bisa produktif dan tidak menimbulkan permasalahan hukum. Begitu pula debitur juga selayaknya memperoleh perlindungan hak dan kewajibannya sesuai dengan prinsip-prinsip hukum perjanjian. Pemberian kredit adalah tulang punggung kegiatan perbankan bila diperhatikan neraca bank, akan terlihat bahwa sisi aktiva bank akan di dominasi oleh besarnya kredit demikian juga sisi pendapatan bank, akan ditemui bahwa pendapatan terbesar bank dari pendapatan bunga dan kredit.(Sinungan, 2000).

Pemberian kredit pada umumnya dilakukan oleh mereka yang memiliki modal atau uang kepada yang membutuhkan (debitur) yang dikuatkan dalam bentuk perjanjian hutang piutang.Mereka yang memberikan kredit adalah pihak bank sebagai kreditur.Antara kreditur dan debitur terikat hak dan kewajiban sebagaimana telah disepakati dalam perjanjian.Pihak kreditur memiliki kewajiban untuk menyerahkan sejumlah uang sebagaimana yang telah disepakati dalam perjanjian kepada debitur dengan harapan dapat menerima uangnya kembali pada waktunya berikut bunga yang telah disepakati oleh para pihak.

Hak dan kewajiban debitur adalah bertimbal balik dengan hak dan kewajiban kreditur. Selama proses ini tidak mebghadapi masalah dalam arti kedua pihak melaksanakan hak dan kewajibannya sesuai dengan perjanjian, maka persoalan tidak akan muncul. Biasanya persoalan muncul jika debitur lalai megembalikan uang pinjaman pada saat yang telah diperjanjikan.(Widjaya, Gunawan, 2001)

Pengamanan kredit merupakan suatu mata rantai kegiatan bank.Langkah pengamanan ini dimulai dari sejak bank merencanakan untuk memberikan kredit.Dalam menyusun rencana dengan sekaligus perhitungan plafond, bank telah memperhitungkan berbagai segi yang dapat dijangkau oleh kemampuan operasional.Mengatur alokasi kredit ke arah sektor-sektor yang favourable diberikan ke nasabah-nasabah mana serta dengan jumlah plafond berapa dan sebagainya, merupakan langkah-langkah untuk menjaga keamanan kredit. 
Dalam menjalankan kegiatan kredit perbankan dibutuhkan suatu pengamanan yang diawali pada saat perencanaan untuk memberikan kredit.Pengamanan ini perlu dilakukan sedimikian rupa karena erat kaitannya dengan risiko oleh karena itulah bank dilarang memberikan kredit tanpa jaminan.

Keberadaan jaminan merupakan hal penting.Undang-Undang Nomor 10 Tahun 1998 memberikan makna yang berbeda antara jaminan dengan agunan.Jaminan merupakan keyakinan bank atas kemampuan dan keanggupan nasabah debitur untuk melunasi kewajiban hutangnya sesuai perjanjian. Oleh karena itu, sebelum kredit diberikan, Bank akan melakukan penilaian terhadap kemampuan, watak, agunan dan modal serta prospek usaha dari debitur. Sedangkan agunan adalah jaminan tambahan yang diserahkan debitur kepada bank dalam rangka pemberian kredit atau pembiayaan berdasarkan prinsip perbankan.(Nugraha, 2016)

Karena kredit yang diberikan oleh bank berisiko, maka dalam pelaksanaannya bank juga harus memperhatikan asas-asas kredit yang sehat.Pengamanan tersebut mencakup pengamanan preventif dan represif.Pengamanan preventif dibentuk mencegah terjadinya kemacetan kredit, sedangkan pengamanan represif dibentuk untuk menyelesaikan kemacetan kredit.Hubungan kreditur dan debitur di bangun atas dasar kontrak atau perjanjian. Perjanjian tersebut harus memenuhi syarat sahnya perjanjian sebagaimana di atur dalam Pasal 1320 KUHPerdata yaitu atau yang mencakup unsur :

a. Sepakat

Supaya perjanjian menjadi sah maka para pihak harus sepakat terhadap segala hal yang terdapat di dalam perjanjian dan memberikan persetujuannya atau kesepakatannya jika ia memang menghendaki apa yang disepakati. Dalam preambule perjanjian (sebelum masuk ke pasal-pasal), biasa tuliskan sebagai berikut "Atas apa yang disebutkan diatas, Para Pihak setuju dan sepakat hal-hal sebagai berikut:" Pencantuman kata-kata setuju dan sepakat sangat penting dalam suatu perjanjian. Tanpa ada kata-kata ini (atau kata-kata lain yang bermaksud memberikan ikatan atau setuju saja atau sepakat saja), maka perjanjian tidak memiliki ikatan bagi para pembuatanya.Setuju dan sepakat dilakukan dengan penuh kesadaran di antara para pembuatnya, yang bisa diberikan secara lisan dan tertulis.

b. Cakap

Pasal 1329 KUHPerdata menyatakan bahwa setiap orang adalah cakap untuk membuat perjanjian, kecuali apabila menurut undang-undang dinyatakan tidak cakap. Kemudian Pasal 1330 menyatakan bahwa ada beberapa orang yang tidak cakap untuk membuat perjanjian, yakni: 
1) Orang yang belum dewasa (dibawah 21 tahun, kecuali yang ditentukan lain)

2) Mereka yang ditaruh di bawah pengampuan (curatele or conservatorship); dan

3) Perempuan yang sudah menikah

c. Hal tertentu

Suatu perjanjian harus mempunyai pokok suatu benda (zaak)yang paling sedikit dapat ditentukan jenisnya. Suatu perjanjian harus memiliki objek tertentu dan suatu perjanjian haruslah mengenai suatu hal tertentu (certainty of terms), berarti bahwa apa yang diperjanjikan, yakni hak dan kewajiban kedua belah pihak. Barang yang dimaksudkan dalam perjanjian paling sedikit dapat ditentukan jenisnya (determinable).

d. Sebab yang halal

Syarat sahnya perjanjian yang keempat adalah adanya kausa hukum yang halal.Jika objek dalam perjanjian itu illegal, atau bertentangan dengan kesusilaan atau ketertiban umum, maka perjanjian tersebut menjadi batal.Sebagai contohnya, perjanjian untuk membunuh seseorang mempunyai objek tujuan yang illegal, maka kontrak ini tidak sah.

Sahnya perjanjian tersebut juga tidak boleh melanggar kesusilaan, undang - undang dan ketertiban umum sesuai Pasal 1337 KUHPerdata. Menurut Undang - Undang nomer 10 tahun 1998 tentang perubahan atas Undang-Undang Nomer 7 tahun 1992 tentang perbankan menyatakan bahwa dalam perjanjian kredit wajib menggunakan jaminan agar perjanjian tersebut tidak berisiko maka sudah sewajarnya kalau yang dijadikan jaminan yang seharusnya atas namadebitur. Jenis pengikatan jaminan kebendaan yaitu hak tanggungan sebagaimana diatur dalam Undang-Undang Nomer 4 Tahun 1996. Kedua adalah gadai sebagaimaa diatur dalam Pasal 1150-1160 KUH Perdata, ketiga jaminan fiducia sebagaimana diatur dalam Undang-Undang Nomor 42 Tahun 1999 tentang Jaminan Fidusia.

Permasalahan dalam penelitian ini adalah pertama, bagaimana pelaksanaan perjanjian kredit dan akibat hukumnya bilamana obyek jaminan bukan atas nama debitur, kedua, bagaimana penyelesaian sengketa bilamana debitur wanprestasi.

\section{B. Metode Penelitian}

Guna memperoleh data yang konkret sebagai bahan dalam usulan penelitian tesis maka penulis menggunakan metode yang merupakan suatu prosedur untuk mengetahui sesuatu, untuk mempunyai langkah - langkah. Menurut Soerjono Soekanto metodologi pada dasarnya 
memberikan pedoman tentang tata cara seorang ilmuwan dalam mempelajari, menganalisa, dan memahami lingkungan yang dihadapinya. (Soekanto, 1995)

Penelitian merupakan suatu sarana pokok dalam pengembangan ilmu pengetahuan maupun tekhnologi.Hal ini disebabkan oleh karena penelitian bertujuan untuk mengungkapkan kebenaran secara sistematis, metodologi dan konsisten. Melalui proses penelitian tersebut diadakan analisa dan konstruksi terhadap data yang telah dikumpulkan dan diolah.

Oleh karena penelitian merupakan sarana ilmiah bagi pengembangan ilmu pengetahuan dan tekhnologi, maka metodologi penelitian yang ditetapkan harus disesuaikan dengan ilmu pengetahuan yang menjadi induknya dan dalam hal ini tidaklah selalu berarti Soerjono Soekanto dan Sri Mamudji, Penelitian Hukum Normatif Suatu Tinjauan metodologi yang digunakan berbagai ilmu pengetahuan pasti akan berbeda secara utuh. Berdasarkan hal tersebut diatas metodologi penelitian hukum juga mempunyai ciri-ciri tertentu yang merupakan identitas, oleh karena ilmu hukum dapat dibedakan dari ilmu-ilmu pengetahuan lainnya.

Penelitian pada dasarnya adalah suatu kegiatan yang terencana yang dilakukan dengan metode ilmiah yang bertujuan untuk mendapatkan data baru guna membuktikan kebenaran ataupun ketidakbenaran dari suatu gejala atau hipotesa yang ada.(Waluyo, 1991)

Secara khusus menurut jenis, sifat dan tujuan suatu penelitian hukum dibedakan menjadi 2 (dua) yaitu : Penelitian hukum normatif dan Penelitian hukum empiris.

Penelitian hukum normatif adalah penelitian doktriner, juga disebut sebagi penelitian kepustakaan atau studi dokumen. Disebut penelitian hukum doktriner karena penelitian ini dilakukan atau ditunjukkan pada peraturan-peraturan yang tertulis atau bahan-bahan hukum yang lain sebagai penelitian atau studi dokumen disebabkan penelitian ini banyak dilakukan terhadap data yang bersifat sekunder yang ada diperpustakaan. Dalam penelitian hukum yang normatif biasanyamdipergunakan sumber-sumber data sekunder saja, yaitu buku-buku, buku harian, peraturan perundang-undangan, keputusan-keputusan pengadilan, teori-teori hukum dan pendapat para sarjana hukum yang terkemuka.

Penelitian Hukum Empiris adalah suatu metode penelitian hukum yang berupaya untuk melihat hukum dalam arti yang nyata atau dapat dikatakan melihat, meneliti bagaimana bekerjanya hukum dalam masyarakat.

a. Metode Pendekatan

Metode penelitian digunakan dalam penelitian ini adalah pendekatan Yuridis Normatif, karena secara yuridis penelitian didasarkan pada pendekatan terhadap asas-asas 
dan aturan-aturan hukum yang berhubungan dengan Kitab Undang-Undang Hukum Perdata, Undang-Undang Perbankan, Peraturan tentang Hak Tanggungan, Pasal 1320 KUHPerdata, buku-buku dan diktat-diktat literatur tentang Perdata,

Dengan menggunakan pendekatan yuridis normatif dimaksudkan untuk mengetahui pengaruh asas-asas hukum, penemuan hukum terhadap suatu Permasalahan tertentu dengan bertumpu pada data sekunder.

b. Spesifikasi Penelitian

Spesifikasi penelitian adalah deskriptif analitis, yaitu menggambarkan suatu Peraturan Perundang-Undangan yang berlaku, dikaitkan dengan teori hukum dan praktik hukum positif yang menyangkut permasalahan, selanjutnya akan dianalisis sebagai jawaban atas permasalahan yang selama ini terjadi, sehingga dengan penelitian ini diharapkan diperoleh gambaran yang menyeluruh dan sistimatis mengenai faktor-faktor yang berhubungan dengan sahnya perjanjian kredit dan akibat hukumnya sehubungan dengan jaminan kredit yang bukan atas nama debitur.

c. Metode Pengumpulan Data

Data yang dikumpulkan dalam penulisan tesis ini meliputi data sekunder, data sekunder adalah data yang mendukung keterangan atau menunjang kelengkapan data primer. Data ini diperoleh dari perpustakaan dan koleksi pustaka pribadi penulis, yang dilakukan dengan cara studi pustaka atau literatur. Data sekunder yang akan digunakan terdiri dari :

a) Bahan-bahan hukum primer, yakni:

Kitab Undang-Undang Hukum Perdata, Perjanjian kredit para pihak, Undang- Undang Nomer 4 tahun 1996 tentang Hak Tanggungan.

b) Bahan hukum sekunder, yaitu: bahan hukum yang memberikan penjelasan mengenai bahan hukum primer yang terdiri dari buku-buku tentang perjanjian, kontrak, hak tanggungan

c) Bahan-bahan hukum tersier berupa kamus, ensiklopedia dan literatur perkuliahan

d. Metode Analisis Data

Analisis data pada penelitian ini dilakukan secara kualitatif normatif, yaitu dari data yang diperoleh kemudian disusun secara sistimatis kemudian dianalisa secara kualitatif untuk mencapai kejelasan terhadap masalah yang akan dibahas. analisis data kualitatif adalah suatu cara penelitian yang menghasilkan data deskriptif analisis.

Pengertian analisis disini dimaksudkan sebagai suatu penjelasan dan penginterprestasian secara logis, sistimatis. Logis sistimatis menunjukan cara berpikir 
deduktif-induktif dan mengikuti tata tertib dalam penulisan laporan penelitian ilmiah. Setelah analisi data selesai maka hasilnya akan disajikan secara deskriptif, yaitu dengan menuturkan dan menggambarkan apa adanya sesuai dengan permasalahan yang diteliti.

\section{Hasil dan Pembahasan}

Sebagaimana Standard Operasional dan Prosedur yang telah ditentukan oleh PT BPR "X" dalam peluncuran kredit kepada debitur, dalam beberapa hal mengalami permasalahan dalam praktik yang menyimpang dari standar operasional dan prosedur. Penyimpangan itu bisa terjadi baik dari mulai tahap permohonan kredit, analisa kredit serta tahap keputusan kredit.Bilamana kesalahan ini terjadi bisa berisiko pada macetnya pembayaran oleh debitur atau akibat hukum lainnya seperti tidak dapat dilakukan lelang penjualan jaminan sebagai akibat wanprestasi.Hal seperti ini terjadi pada PT BPR "X" Kota Semarang melalui persetujuan membuka kredit dengan debitur yang bertempat tinggal di Kota Semarang.

Posisi kasusnya diawali dengan kesepakatan perjanjian kredit (nama kontraknya Persetujuan Membuka Kredit) antara PT BPR "X" dengan Debitur perorangan Dalam Persetujuan Membuka Kredit Nomor 0004/KSB.003/BJK/II/2014. Dalam perjanjian ini telah disetujui untuk sejumlah pinjaman uang sebesar Rp 1.500.000.000 (satu milyar lima ratus juta rupiah) dengan bunga 1,17\%/bulan atau 14\%/tahun (Pasal I). Jangka waktu pinjaman adalah 6 (enam) bulan terhitung sejak tanggal 5 Pebruari 2014 hingga akan berakhir tanggal 5 Agustus 2014 (Pasal V ayat 1).

Dalam pinjaman kredit ini sebagaimana ditentukan dalam Pasal XI, debitur menyerahkan jaminan sebagai berikut:

- Sebidang tanah bersertifikat Hak Milik No. 1093, luas tanah + 11.300 m2, tanah tersebut terletak di Kp. Gedawang RT 02 RW 02, Kelurahan Gedawang, Kecamatan Banyumanik Semarang a/n Kalwi (bukan milik debitur).

- $\quad$ Sebidang tanah bersertifikat Hak Milik No.2515, luas tanah + $244 \mathrm{~m} 2$, luas bangunan +301 m2, tanah beserta bangunan terletak di Jatingaleh 2 No. 306, Kelurahan Ngesrep, Kecamatan Banyumanik Semarang.

Pada waktu debitur tanda tangan PMK (Persetujuan Membuka Kredit) di kantor BPR, debitur memberikan keterangan bahwa sertifikat Hak Milik No. 1093 berada di notaris dan dalam proses balik nama dari pemilik (Kalwi) ke pembeli/debitur. Namun pada waktu debitur memberikan keterangan tersebut, pihak legal kantor maupun komite kredit tidak memverifikasi 
kebenaran keterangan yang diberikan debitur tersebut. Kemudian setelah selesai tanda tangan PMK di kantor BPR, keluarlah dana sesuai pengajuan debitur tersebut.

Setelah pencairan, pihak bank kurang memonitoring debitur tersebut sehingga terjadilah keterlambatan pembayaran bunga pada bulan pertama dan seterusnya sampai jatuh tempo pada tanggal 05 Agustus 2014.Usaha debitur mengalami penurunan yang mengakibatkan usaha debitur bangkrut, sehingga pinjaman debitur di PT BPR " $X$ " mengakibatkan debitur tidak bisa mengembalikan uang bank BPR hingga dengan sekarang.

Setelah dilakukan verifikasi, ternyata sertifikat yang dijadikan jaminan di bank dengan Sebidang tanah bersertifikat Hak Milik No. 1093, luas tanah $+11.300 \mathrm{~m} 2$, tanah tersebut terletak di Kp. Gedawang RT 02 RW 02, Kelurahan Gedawang, Kecamatan Banyumanik Semarang a/n Kalwi tidak bisa dibalik nama karena belum ada proses jual beli antara Kalwi dengan Debitur, sedangkan Kalwi baru diberikan Uang Muka sebesar Rp. 50.000.000,- (Lima Puluh Juta Rupiah). Debitur menjanjikan kekurangannya akan diberikan kepada pihak penjual setelah pengajuan kredit debitur disetujui pihak bank. Namun kenyataannya, debitur wanprestasi kepada kreditur maupun penjual, padahal sertifikat berada di kreditur (PT.BPR “X”).

Dari masalah tersebut, dapat dianalisis bahwa kesalahan utama terjadi pada saat tahap permohonan kredit.Semestinya, pihak Tim Analisis Kredit PT BPR " $X$ " harus hati-hati dan cermat di dalam memberikan rekomendasi persetujuan. Kurang cermatnya terletak pada spekulasi terhadap jaminan sebidang tanah bersertifikat Hak Milik No. 1093, luas tanah +11.300 m2, tanah tersebut terletak di Kp. Gedawang RT 02 RW 02, Kelurahan Gedawang, Kecamatan Banyumanik Semarang a/n Kalwi, bukan atas nama debitur. Standar operasional prosedur telah dilanggar oleh analisis kredit sehingga kesalahan tersebut ada pada internal PT BPR " $X$ ”. Kasus ini jelas melanggar prinsip kehati-hatian sebagaimana diatur dalam Surat Keputusan Direktur Bank Indonesia No. 27/162/KEP/DIR tanggal 31 Maret 1995. Prinsip Kehati-hatian adalah suatu asas yang menyatakan bahwa bank dalam menjalankan fungsi dan kegiatan usahanya wajib menerapkan Prinsip Kehati-hatian dalam rangka melindungi dana masyarakat yang dipercayakan padanya. Hal ini disebutkan dalam Pasal 2 Undang-Undang Nomor 10 tahun 1998 Tentang Perbankan, bahwa perbankan Indonesia dalam melaksankan usahanya berasaskan demokrasi ekonomi dengan menggunakan asas kehati-hatian. Tujuan diberlakukannya prinsip kehati-hatian tidak lain adalah agar bank selalu dalam keadaan sehat. Dengan diberlakukannya prinsip kehatihatian diharapkan agar kepercayaan masyarakat terhadap perbankan tetap tinggi, sehingga masyarakat bersedia dan tidak ragu-ragu menyimpan dananya di bank. Dalam prinsip kehatihatian terhadap 5C of Credit yang meliputi character (watak), capacity (kemampuan), capital 
(modal), collateral (agunan), condition of economy (prospek usaha dari debitur) yang dimana prinsip 5C ini merupakan prinsip yang saling terkait satu dengan yang lainnya sehingga tidak dapat dipisahkan atau dikesampingkan. Aspek collateral (agunan) merupakan aspek yang menonjol dalam pelanggaran SOP PT BPR "X", mengingat jaminan yang digunakan bukan atasnama debitur, sedangkan aspek yang lain adalah aspek condition of economy yaitu analisis keberlangsungan proyek debitur.

Jika dilihat keabsahan perjanjian sebagaimana diatur dalam Pasal 1320 KUHPerdata, maka secara substansial, Persetujuan Membuka Kredit Nomor: 0004/KSB.003/BJK/II/2014 telah sah dan telah memenuhi unsur subyektif dan unsur obyektif. Begitu pula bilamana ditinjau dari teori Schuld dan haftung, debitur tidak menjalankan kewajiban atau prestasi sebagaimana yang telah diperjanjikan.Oleh karena itu, jika debitur tidak mau membayar hutang maka harta bendanya yang dijadikan jaminan harus disita. Namun, pelaksanaan schuld dan haftung tidak bisa dilaksanakan sebagaimana seharusnya dikarenakan salah satu jaminan tidak bisa dilakukan sita dikarenakan bukan milik atau atas nama debitur. Selain itu, tidak ada kuasa dari pemilik tanah yang ditujukan kepada debitur tentang persetujuan dan kuasa menjual bilamana debitur wanprestasi atas hutang atau kredit dari PT BPR "X", meskipun Surat Kuasa Untuk Menjual menyebutkan sebidang tanah HM No: 1093 a/n Kalwi.

Perjanjian kredit antara para pihak tetap sah, namun ketika debitur tidak menjalankan kewajibannya dikarenakan mengalami kerugian dalam usahanya bahkan telah mengalami bangkrut, maka terhadap jaminan sebidang tanah bersertifikat Hak Milik No. 1093 tidak bisa dijual meskipun telah dibuat Surat Kuasa Menjual. Akibat hukumnya adalah PT BPR " $X$ " tidak bisa menjual jaminan debitur yang bukan atas namanya, meskipun sertifikat jaminan sebidang tanah tersebut tetap dikuasai oleh PT BPR "X". Posisinya menggantung dalam arti tidak bisa dilakukan lelang sebagai kompensasi hutang. Bahkan, ada peluang pengajuan gugatan oleh yang punya hak atas tanah yang dijadikan jaminan tersebut, kepada debitur dan kreditur atas dasar perbuatan melawan hukum (Pasal 1365 KUHPerdata) mengingat bahwa hubungan hukum antara pemilik tanah dengan debitur adalah jual beli tanah yang tidak pernah terlaksana atau tidak pernah terjadi transaksi jual beli tanah. Pasal 1365 KUHPerdata menentukan bahwa tiap perbuatan melawan hukum yang mengakibatkan kerugian pada orang lain, mewajibkan orang yang melakukan perbuatan tersebut untuk mengganti kerugian.Oleh karena itu, PT BPR "X" secara hukum berada pada posisi yang tidak menguntungkan dan berisiko akan digugat oleh pihak pemilik tanah dikarenakan menguasai hak atas tanah tanpa ada persetujuan secara formil daripadanya. 
Dilihat dari aspek Hak Tanggungan, maka berdasarkan Pasal 6 Undang-Undang Nomor 4 Tahun 1996 Tentang Hak Tanggungan Atas Tanah Beserta Benda-Benda Yang Berkaitan Dengan Tanah, dikatakan bahwa "apabila debitor cidera janji, pemegang Hak Tanggungan pertama mempunyai hak untuk menjual obyek Hak Tanggungan atas kekuasaan sendiri melalui pelelangan umum serta mengambil pelunasan piutangnya dari hasil penjualan tersebut". Namun dengan tidak adanya sertifikat hak tanggungan, meskipun sertifikat tanah hak milik dikuasasi oleh kreditor, maka kreditor tidak punya hak untuk menjual obyek atas tanah Hak Milik No. 1093 atas kekuasaan sendiri melalui pelelangan umum.

\section{Simpulan}

Pelaksanaan perjanjian kredit pada PT BPR "X" pada kasus Perjanjian Membuka Kredit No. 0004/KSB.003/BJK/II/2014 dengan debitur bernama Trusto Wardoyo telah melanggar prinsip kehatian-hatian sebagaimana diatur dalam Undang-Undang No. 10 Tahun 1998 Tentang Perbankan dan Peraturan Bank Indonesia No.7/2005 Jo PBI

No.8/2005. Dari aspek internal, PT BPR “X” juga tidak menjalankan Standar dan Operasional Prosedur (SOP) terhadap 5C of Credit yang meliputi character (watak), capacity (kemampuan), capital (modal), collateral (agunan), condition of economy (prospek usaha dari debitur). Collateral merupakan isu utama atau sebagai faktor yang menyebabkan kreditur dalam posisi lemah dikarenakan jaminan sertifikat hak atas tanah No. 1093 sebagaimana dituangkan dalam perjanjian kredit tersebut di atas bukan atas nama debitur. Ada kelalaian dalam pemeriksaan tahap pengajuan kredit yang sejak awal mestinya sudah diketahui bakal memiliki risiko hukum yang sebetulnya tidak perlu terjadi.Tim analis kredit sudah semestinya juga mengetahui kelemahan pengajuan kredit tersebut namun dilakukan pembiaran hingga terjadi persetujuan perjanjian kredit.Dengan adanya wanprestasi oleh debitur sudah bisa diduga sebelumnya serta akibat hukumnya.Akibat hukumnya adalah jaminan sertifkat hak atas tanah No 1039 tidak bisa dieksekusi karena jaminan tersebut bukan milik debitur sehingga PT BPR “X” mengalami kerugian ketika Debitur wanprestasi. Perjanjian kreditnya sendiri adalah sah sesuai Pasal 1320 KUHPerdata, namun kreditur tidak bisa melakukan penjualan melalui lelang sebagaimana diatur dalam Pasal 6 Undang-Undang No. 4 Tahun 1996 Tentang Hak Tanggungan Atas Tanah Beserta Benda-Benda Yang Berkaitan Dengan Tanah.

Penyelesaian senngketa melalui Alternatif Penyelesaian Sengketa merupakan cara yang paling tepat mengingat kedudukan jaminan yang tidak bisa dijual. Namun, penyelesaian 
ini akan membantu kreditur bilamana debitur tidak dalam keadaan kolap dan masih memiliki itikad baik dan didukung adanya aset lain sebagai pengganti. Dengan kolapnya debitur, maka upaya penyelesaian sengketa alternatif juga bersifat sepekulatif sehingga tidak begitu signifikan dan tidak mampu menyelesaikan masalah.Kreditur dalam hal ini mengalami kerugian besar dengan tidak dibayarnya bunga dan pinjaman pokok.Hal ini dikarenakan kecerobohan PT BPR "X" melalui staf-stafnya yang melanggar prinsip kehati-hatian sebagaimana diatur dalam Peraturan Bank Indonesia No.7/2005 Jo PBI No.8/2005. Bahkan, pemilik tanah memiliki kesempatan atau hak untuk melaporkan kepada Polisi atas dasar perbuatan penggelapan baik kepada debitur maupun kepada PT BPR “X”.

Berdasarkan simpulan diatas, maka disampaikan saran sebagai berikut :

a. Hendaknya PT BPR "X” untuk segera menyelesaikan secara "win-win solution" melalui tiga pihak yaitu kreditur, debitur maupun pemilik sertifikat tanah hak milik No 1093 atas nama Kalwi. Potensi tuduhan penggelapan terhadap kreditur bisa mungkin terjadi

b. Standar operasional prosedur perlu ditegakkan dikalangan staf PT BPR "X" agar dengan cermat mengimplementasikan prinsip-prinsip kehati-hatian

c. Melakukan monitoring dan evaluasi terhadap kinerja para staf PT BPR "X" agar dalam pemberian pinjaman benar-benar memperhatikan 5C (character, capacity, capital, collateral, condition of economy. 


\section{DAFTAR PUSTAKA}

Nugraha, A. (2016). Tinjauan Yuridis Perlindungan Hukum Bagi Kreditur Dalam Perjanjian Kredit Dengan Jaminan Persediaan Barang Dagangan Pada PT BNI Cabang Muaro Bungo. Universitas Diponegoro.

Sinungan, M. (2000). Manajemen Dana Bank. Jakarta: Bumi Aksara.

Soekanto, S. (1995). Penelitian Hukum Normatif Suatu Tinjauan Singkat (4th ed.). Jakarta: Raja Grafindo Persada.

Waluyo, B. (1991). Penelitian Hukum. Jakarta: Sinar Grafika.

Widjaya, Gunawan, E. al. (2001). Jaminan Fidusia. Jakarta: PT Raja Grafindo Persada. 